\title{
"Assessment for Learning" in UK Higher Education and its Implications for Foreign Language Teaching in China
}

\author{
$\mathrm{Li} \mathrm{Li}^{1}$ Guo Qingzhu ${ }^{2}$ \\ ${ }^{1}$ Tianjin Polytechnic University, Tianjin 300387, China \\ ${ }^{2}$ Tianjin Polytechnic University, Tianjin 300387, China
}

\begin{abstract}
In order to advance EFL students' all-round development and enhance life-long learning, changes to assessment practices in Chinese higher education need to be made.

By learning from best practice in UK higher education institutions, Chinese universities should adopt and put more emphasis on Assessment for Learning (AfL), a process in which educators identify and diagnose student learning problems, and provide quality feedback to students on how to improve, instead of relying solely on summative techniques.
\end{abstract}

Keywords: UK; higher education; Assessment for Learning (AfL); Foreign Language Teaching (FLT); feedback

\section{Introduction}

From 1999 in the UK, the Assessment Reform Group (ARG), which is composed of senior university staff and researchers, has been at the forefront of all aspects of assessment. It defines Assessment for Learning as "the process of seeking and interpreting evidence for use by learners and their teachers to decide where the learners are in their learning, where they need to go and how best to get there".

Furthermore, the ARG influenced Black and Wiliam (2001: 2) and their seminal paper "Inside the Black Box" where they answered the question 'Is there evidence that improving formative assessment raises standards?' with a definite 'yes'. Additionally, the process of implementing Assessment for Learning was laid out in the paper "Assessment for learning: putting it into practice" which was adapted and incorporated into training materials sent out to every school to be used as part of in-service training and incorporated into the school inspection process.

Thus Assessment for Learning recognizes the full range of achievements of all learners and although it originally started in primary and secondary schools in Britain and quickly spread to higher education in various fields of studies at home and abroad.

\section{Principles of Assessment for Learning}

In 2002, ARG published 10 principles for Assessment for Learning to enhance classroom practice. Assessment for learning:

- should be part of effective planning of teaching and learning.
- $\quad$ should focus on how students learn.

- should be recognized as central to classroom practice.

- should be regarded as a key professional skill for teachers.

- $\quad$ should be sensitive and constructive because any assessment has an emotional impact.

- should take account of the importance of learner motivation.

- $\quad$ should promote commitment to learning goals and a shared understanding of the criteria by which they are assessed.

- learners should receive constructive guidance about how to improve.

- develops learners' capacity for self-assessment so that they can become reflective and self-managing.

- should recognize the full range of achievements of all learners.

\section{Assessment for Learning and Assessment of Learning}

Below is a summary of the differences between Assessment for Learning and Assessment of Learning.

Table 1: Comparison and contrast of Assessment for Learning and Assessment of Learning

\begin{tabular}{|c|c|}
\hline $\begin{array}{l}\text { Assessment for } \\
\text { Learning }\end{array}$ & $\begin{array}{l}\text { Assessment of } \\
\text { Learning }\end{array}$ \\
\hline Various formalities & $\begin{array}{l}\text { Mainly written } \\
\text { tests }\end{array}$ \\
\hline $\begin{array}{l}\text { Teaching and } \\
\text { assessment } \\
\text { combined }\end{array}$ & $\begin{array}{c}\text { Teaching and } \\
\text { Assessment } \\
\text { separated }\end{array}$ \\
\hline $\begin{array}{l}\text { Formative } \\
\text { evaluation }\end{array}$ & $\begin{array}{l}\text { Summative } \\
\text { evaluation }\end{array}$ \\
\hline $\begin{array}{l}\text { Students actively } \\
\text { participating in } \\
\text { evaluation }\end{array}$ & $\begin{array}{l}\text { Students } \\
\text { evaluated }\end{array}$ \\
\hline $\begin{array}{l}\text { Both teacher and } \\
\text { students assess }\end{array}$ & Teacher assesses \\
\hline $\begin{array}{c}\text { Assessment } \\
\text { standards specific }\end{array}$ & $\begin{array}{c}\text { Assessment } \\
\text { standards not } \\
\text { specific }\end{array}$ \\
\hline $\begin{array}{l}\text { Descriptive } \\
\text { feedback }\end{array}$ & $\begin{array}{l}\text { Diagnostic } \\
\text { feedback }\end{array}$ \\
\hline
\end{tabular}


Assessment of Learning focuses on grading and reporting, whereas the primary purpose of Assessment for Learning is in its utility to inform teaching and therefore promote learning.

\section{FLT assessment in China}

How many students know about the writing and translation marking standards of College English Band 4 \& 6 Tests considering they are the most influential tests in the country? Answer - not many.

Chinese foreign language teaching still rigidly adheres to the Assessment of Learning model, so teaching and assessment are separated from each other. Also, students do not get any advice or feedback beyond a raw numerical score from midterm and final exams.

Take the undergraduate English listening and oral course for example, a number of Chinese universities use $\mathrm{New}$ Standard College English published by the Foreign Language Teaching and Research Press. The textbook is very practical and rich with English culture. However, when it comes to the way of using the textbook, problems appear. Usually video recordings are played again and again if students do not understand them, but teachers rarely explain why students cannot understand the stories or where the difficulties lie, or how to improve students' listening comprehension.

The course usually only has the final exam, which uses forms similar to those used in College English Band 4 Test. Furthermore, to our surprise, the teaching/textbook content and test content are completely unrelated. When it comes to oral English, students get even fewer opportunities and less feedback. This kind of teaching is of limited use to students and can never achieve the optimum learning results and objectives.

\section{How to improve Chinese FLT assessment quality and standard}

When considering improving Chinese FLT assessment, the most important element is that we have to obtain the support of education policy makers from within the Chinese government and from individual institutions. After this prerequisite is met, we also need to do the following:

\subsection{Informing students of the course objectives and evaluation standards}

EFL teachers should inculcate their students about learning objectives, learning outcomes, forms of assessment, and grading standards, so that they know exactly what they are learning, its scope and what their learning goals are.

\subsection{Evaluation should be ongoing and continuous}

Assessment for Learning should apply to the whole process of teaching, because it is an important part of the teaching and learning process. During evaluation of students, EFL teachers should try to observe whether students have mastered the knowledge and language skills outlined in their lesson planning. From the performance of students, teachers should make an adjustment to their teaching methods according to the students' abilities. Thus the final examination is only considered as a comprehensive summary of students' performance, therefore it cannot replace assessment for the duration of the course.

\subsection{Self-assessment and peer-assessment}

Assessment for Learning emphasizes students' participation as well as teacher's evaluation, so that students become learning resources for each other as they try to achieve their learning objectives. During this iterative process of feedback from ongoing self-assessment and peerassessment, students can become aware of their own progress and be able to isolate and overcome any difficulties in their studies. EFL teachers can adjust their teaching methods when necessary in order for students to achieve the best results.

\subsection{Providing effective feedback}

Assessment for Learning stresses providing students with informative feedback to diagnose problems, and provide effective learning strategies to solve them. EFL teachers should aim to supply constructive feedback according to the performance of students and highlight any gaps or obstacles which lie between their performance and their learning goals.

In order to better understand and achieve best practice using Assessment for Learning and its 10 principles, in the Appendix of this paper there is a real example of an oral English course assessment which was successfully delivered in China and is attached for reference.

\section{Conclusion}

EFL teachers need to pay more attention to the way students learn. At the beginning of a language course, teachers and students should assess to get to know the learners' language level. During and at the end of the course, specific guidance, constructive comments and suggestions as to how students address the next step in learning should be included as feedback.

Evaluation is not just for its own sake, but is a tool to enable students to study effectively and achieve their full potential. Therefore, students' learning is the main goal for 
EFL teachers to bear in mind. By giving students only numerical marks for the final examination cannot solve any specific learning problems. Teachers should be always ready to point out each student's specific study difficulties, the direction in which they should be concentrating their efforts, and develop effective learning strategies. In order to motivate students to make great progress quickly and steadily, establishing an appropriate and proper evaluation or assessment system is very important in foreign language teaching and learning. We must remember that assessment is what educators focus on, but learning is the ultimate goal.

\section{Acknowledgements}

This paper is dedicated to two Tianjin municipal research projects entitled:

1."A Study Comparing and Contrasting Chinese and Foreign Higher Education in terms of Assessment Quality and Standards", sponsored by the $12^{\text {th }}$ Tianjin Five-year Education Planning Project in 2012, Ref. HE4077).

2."Research into Foreign Language Assessment Systems in the World's Developed Countries", sponsored by the $12^{\text {th }}$ Education and Science Planning Key Project from Tianjin Higher Education Association in 2012, Ref. 125Z012).

This paper is also written for "A Comparative Study of Politeness Principles in English and Chinese from the Perspective of Pragmatics", a project sponsored by the Tianjin Philosophy and Social Sciences Planning Funds, Ref. TJWW13-023).

\section{References}

[1] Assessment Reform Group. "Assessment for Learning: 10 principles", 2002.

[2] Black, P. J. \& Wiliam, D. "Inside the Black Box: Raising standards through classroom assessment". King's College, London, 1998.

[3] Black, P. J., Harrison, C., Lee, C., Marshall, B. \& Wiliam, D. "Assessment for learning: putting it into practice" Maidenhead, Open University Press, 2003.

[4] Guo, Qingzhu. "American standards for foreign language learning and its implications for foreign language teaching in China". Concepts and Methodology: Foreign Language Research Papers. pp.1-3, 2014.

[5] Hu, Wenzhong. "A matter of balance - reflections on China's foreign language policy in education". Foreign Language Teaching and Research. Vol 33 (4), 2001. 